\title{
Analysing Judgments from a Feminist Perspective
}

Rosemary Hunter

Professor of Law and Socio-Legal Studies

Queen Mary University of London

Mile End Road

LONDON E1 4NS

rosemary.hunter@qmul.ac.uk

Abstract: This article, by Rosemary Hunter, is based on a presentation given at the national training day on Law, Gender and Sexuality: Sources and Methods in Socio-Legal Research in May 2014, jointly sponsored by the Institute of Advanced Legal Studies, the Socio-Legal Studies Association and the British Library. She begins by describing the uses of judgments as sources within feminist research on judging, and then outlines three different methods of analysis employed within this research: quantitative analysis, qualitative analysis, and the newest method, that of rewriting judgments.

Keywords: judgments; quantitative methods; qualitative methods; discourse analysis; content analysis; rewriting judgments; feminist judgment projects.

Word length: 3214 (including this page)

Biography: Rosemary Hunter is Professor of Law and Socio-Legal Studies at Queen Mary, University of London, where she teaches family law, feminist jurisprudence and research methods. Her research focuses on family law processes, access to justice, and feminist judging. She was one of the organisers of the UK Feminist Judgments Project, and is the current chair of the Socio-Legal Studies Association. 


\section{Introduction}

Feminist research on judging has asked questions such as: How do judges construct gender and sexuality? Do women judges make a difference, and if so how? Do feminist judges make a difference and if so how? Can we identify particular techniques or strategies of feminist judging? Can feminist theory be incorporated into judicial reasoning and if so, to what extent? Like much mainstream legal research, this kind of feminist research uses judgments as its primary source, but unlike mainstream legal research, it considers and analyses judgments in a variety of different ways. This article begins by describing the uses of judgments as sources within feminist research on judging, and then outlines three different methods of analysis employed within this research: quantitative analysis, qualitative analysis, and the newest method, that of rewriting judgments.

\section{Judgments as Sources}

Mainstream legal research tends to focus on individual judgments on a particular topic, and engages in doctrinal analysis, considering how the judgment deals with the facts of the case and how it fits with, extends or departs from existing legal doctrine on the relevant topic. Feminist researchers also engage in this type of analysis, but in addition, in thinking about how judges construct gender and sexuality, they employ discourse analysis rather than doctrinal analysis in reading judgments. Discourse analysis involves paying close, critical attention to the judicial reasoning, including the language and concepts used, the way the argument is constructed, and what might be absent from or excluded by the text. The aim is to identify what understanding/s of gender and/or sexuality are invoked or constructed by the judgment, to place the judgment within the context of wider legal and non-legal discourses around gender and sexuality, and to consider the potential socio-legal effects of the judgment.

As well as analysing individual judgments, some feminist researchers have been concerned with collective judgments - such as, for example, the collective work of a particular court, or of a particular judge, over a period of time. Considering judgments on this scale provides a more systematic way of answering questions about whether women judges or feminist judges make a difference. In the following section I give some specific examples of uses of collective judgments, before returning to individual judgments in the context of feminist judgment projects.

\section{Methods for Analysing Judgments}

Quantitative methods - Within the political science discipline in the USA, there have been a number of studies which have sought to determine whether women judges make a difference by reference to large-scale datasets of judgments. These studies seek to determine whether there is any statistically significant correlation between the outcome of the case or the vote cast by a judge on an appellate panel and the judge's gender, or whether the presence of a woman or women judges on an appellate panel makes any difference to outcomes. Further, by means of regression analysis, they seek to determine whether gender remains statistically significant when other potential explanatory variables (such as the judge's years of experience and political affiliation) are taken into account. The 
results of these studies have been mixed, with some finding no gender differences, ${ }^{1}$ while others have found gender differences in relation to particular issues such as employment discrimination (particularly sex discrimination and sexual harassment), obscenity and private economic matters. ${ }^{2}$ In criminal law, studies have found women judges to be harsher sentencers and more conservative than male judges in relation to crime, ${ }^{3}$ but more liberal than male judges in death penalty cases (Songer and Crews-Meyer 2000). ${ }^{4}$ As well as the subject-matter examined, the results achieved are also influenced by the forms of measurement adopted. ${ }^{5}$

My own research has included a study of the judgments of a particular judge, Justice Marcia Neave, during her first three years on the Court of Appeal in the Australian State of Victoria. ${ }^{6}$ Before her appointment, Justice Neave had had a career as a feminist academic and law reform commissioner, so I was interested to see how she acted as a judge. My statistical analysis included the number of cases on which she sat (204), the types of cases (60 per cent criminal/sentencing appeals), the types of judgments she delivered (leading judgment: 28 per cent; agreement with the leading judgment: 36 per cent; joint judgment: 17 per cent) and her dissent rate (a very low 3 per cent). I also attempted to identify the proportion of cases on which she sat which raised any kind of gender or feminist issue, and found only around one third of her cases did so, most of which were criminal or sentencing appeals. She gave the leading judgment in 36 per cent of these cases, higher than her overall percentage of leading judgments, indicating that she chose to write or was assigned the leading judgment in at least some of the cases due to her particular interest or expertise. She was also more likely to write a concurring judgment in such cases - 15 per cent compared to 8 per cent overall - often to express a particular feminist perspective.

Currently, Erika Rackley and I are undertaking a similar systematic analysis of Lady Hale's judgments on the UK Supreme Court, asking similar questions, but also comparing Hale's statistical profile with those of her judicial colleagues. To date, we have analysed cases from the court's inception in October 2009 until July 2014 (326 cases). We have found a lower proportion of cases raising gender or feminist issues - only 26 per cent - but Lady Hale is significantly more likely to sit on those cases than she is to sit on cases which do not raise such issues. Unlike the Victorian Court of Appeal, the UK Supreme Court's caseload is much more heavily weighted towards civil law, and thus the feminist/gender issues arise in areas such as family law, immigration law, human rights law, housing law and employment law.

Qualitative methods - But a quantitative analysis of judgments can only take you so far. In particular, quantitative analyses focus on the outcomes of cases (finding for the plaintiff or defendant, upholding or dismissing the appeal, or in sentencing cases, the type and duration of sentence imposed). But the feminist literature suggests that women or feminist judges may reason as well as decide differently. Indeed, as indicated above in relation to Justice Neave's concurrences - they may reach the same result as the other members of the court but for different reasons. ${ }^{7}$ In my study of Justice Neave's judgments, therefore, in addition to the quantitative analysis, I undertook a qualitative analysis of her opinions in the cases raising feminist or gender issues, in order to see whether her reasoning in these cases was different from those of her male and other female colleagues. I found there to be much more notable differences than the quantitative study alone might have suggested. 
The most typical way in which Justice Neave 'made a difference' was in making generalised statements which brought previously excluded social experiences of sexual offences and domestic violence into legal discourse, to expand and transform law's 'common knowledge' about the world. In doing so, she challenged gender stereotypes and assumptions about how victims ought to behave. This was not a feature of the judgments of any of her judicial colleagues, male or female. In other cases, Justice Neave contextualised the issues in the case in a way that her judicial colleagues did not, both in terms of explaining the policy context of legislation, and paying attention to the particular circumstances of the individual parties. As indicated above, she arrived at the same result as her colleagues in the vast majority of cases. But in a number of these her different reasoning made an important contribution to the law's ability to understand the full variety of human experience. In our study of Lady Hale's judgments, we are proposing to follow a similar method to analyse reasoning as well as results.

Another example of qualitative analysis of a body of judgments is Kylie Burns' study of the use of 'social facts' by the High Court of Australia in negligence cases. ${ }^{8}$ 'Social facts' are "general statements about the nature and behaviour of people and institutions and the nature of the world and society" ${ }^{\prime 9}$ which may be referred to in the course of judicial reasoning. Burns undertook a systematic content analysis of 45 Australian High Court negligence cases from 2001-2005. She found that social facts were used in these cases for purposes including "predicting social, economic and behavioural consequences of legal rules", ${ }^{10}$ setting the context or background to the case, or as an aid to evaluating facts in issue. Although they were not a major feature of the cases studied, they did play a significant role in certain complex and important cases. Interestingly, most statements of social fact "were not sourced or referenced in any way", 11 but were taken as "common knowledge' by the judges who made them. Burns raises concerns about "potential dangers [for the] accuracy and legitimacy of judicial decision-making". ${ }^{12}$ The 'social facts' enunciated by an all-male court might, for example, differ markedly from the 'feminist common knowledge' set forth in Justice Neave's judgments.

A further example of this kind of approach is a study I am currently undertaking with Danielle Tyson at Monash University in Australia. In 2005 the State of Victoria abolished provocation as a defence to homicide. One of the concerns raised at the time, however, was that the kind of reasoning which had underpinned the provocation defence - that a woman's infidelity or even threats to leave a relationship were sufficient to provoke her male partner to lose self-control and kill her - would reappear as a mitigating factor at the sentencing stage, resulting in more lenient sentences for men who killed their intimate partners or ex-partners. We are thus examining all of the post-provocation sentencing judgments in such cases, to determine whether this is in fact occurring. Again, we are undertaking a content analysis of these judgments, identifying and analysing judicial statements about provocation, domestic violence, men's anger, women's behaviour, the influence of drugs and alcohol, culture and psychological factors. Although the analysis is at a relatively early stage, we have identified one judge, Justice Betty King, whose sentencing judgments stand out from those of both her male and female colleagues in upholding the spirit of the abolition and reinforcing its rationale. 
Rewriting judgments - The third and relatively newly invented method of analysing judgments can be seen in a series of feminist judgment projects, beginning with the Women's Court of Canada. The Women's Court was founded by a group of feminist lawyers and academics who were involved in the Canadian Women's Legal Education and Action Fund (LEAF). LEAF had written a number of amicus briefs in cases before the Canadian Supreme Court dealing with s.15 - the equality clause - of the Canadian Charter of Rights and Freedoms. Although the Court had been responsive to LEAF's arguments in earlier cases, there was a feeling it had stopped listening, and that its equality jurisprudence was going backwards. In thinking about how to regain the Court's attention, they came up with the idea of rewriting the judgments in leading s.15 cases, to demonstrate what their arguments in favour of a more substantive conception of equality would look like in practice. ${ }^{13}$ The first six judgments of the Women's Court of Canada were published in the Canadian Journal of Women and the Law in 2008. ${ }^{14}$

The Women's Court of Canada was followed in 2008-10 by the UK Feminist Judgments Project. Rather than confining itself to a specific area of jurisprudence, the UK project invited participants to rewrite judgments across the whole range of English law. A book containing 23 rewritten judgments, with accompanying explanatory commentaries, was published in 2010. ${ }^{15}$ Subsequently, feminist judgment projects have been launched in Australia, ${ }^{16}$ Ireland (including Northern Ireland) ${ }^{17}$ and the United States, ${ }^{18}$ and there is also a feminist international judgments project beginning work, with the aim of rewriting judgments from a range of international courts and tribunals. ${ }^{19}$ One particular international court - the European Court of Human Rights - has been the subject of a separate project which rewrote a number of the court's judgments in cases involving women's, children's and minority rights, ${ }^{20}$ and a further Children's Rights Judgments Project is also under way.

The aims of the various feminist judgment projects are similar. In light of the fact that the higher judiciary in all common law countries remains significantly male-dominated, the projects imagine the 'missing' feminist judges who might have been on the relevant court, and the judgments they might have written. In doing so, they have put feminist theory into practice in the form of legally plausible judgments, and explored the scope for (and limitations of) doing so. By working within the law at the time of the original judgment, with the material available to the original judges, and using standard techniques of legal reasoning, the re-written judgments demonstrate powerfully the contingency of the original decisions. They show that even at the same time and subject to the same constraints as the original decision-makers, the judgments could have been reasoned and/or decided differently.

In fact, two different methods of rewriting judgments have already developed. The first involves writing an entire judgment, which is intended either to substitute for the original (in the case of a first instance decision) or to be an additional opinion in an appellate case, or to be the decision made by a fictional court hearing an appeal or review of the original decision. Where the opinion is that of an additional judge, it may be a concurrence - which agrees with the original result, but for different reasons - or a dissent, which would have reached a different result from the original court or majority. A further example of this type of alternative judgment is that written by Madhumanti Mukherjee in the Indian Supreme Court Case of Sakshi v Union of India. This case concerned the definition of rape in the 
Indian Penal Code, and Mukherjee argues that women were not treated as legal person under the law. Her feminist judgment seeks to demonstrate how the case would have been decided if women were considered to be legal persons, with a different result from that reached in the original case. ${ }^{21}$

The second method involves a more limited editing of the original judgment rather than writing an entirely new one. Within this method, the original judgment is left largely intact, but particular paragraphs, lines and words may be added, deleted or amended, showing how, with some revision, the judgment could be strengthened or redirected. This was the method used in the European Human Rights Project, and was also the method adopted by Tamara Hervey in a book chapter titled 'Re-judging Social Right in the European Union', in which she undertakes an imaginative, partial rewriting of the Kohll case, ${ }^{22}$ a case on free movement of cross-border patients, to demonstrate how EU social rights - specifically the 'right to health care' - could be made central to judicial reasoning. ${ }^{23}$

\section{Conclusion}

While doctrinal and discursive analysis of individual judgments, and large-scale quantitative analysis of court decisions, are well established methods, the use of judgments as sources, either collectively or individually, to answer other kinds of questions about the way law operates is relatively under-developed. The combination of quantitative and qualitative analysis of the oeuvre of individual judges, content analysis of particular bodies of jurisprudence, and the emerging methods of rewriting judgments, open up a world of possibilities to be explored. I hope this article gives some taste of the possibilities and might inspire and encourage other socio-legal scholars to pursue them.

\footnotetext{
${ }^{1}$ E.g. John Gruhl, Cassia Spohn and Susan Welch, 'Women as Policy Makers: The Case of Trial Judges' (1981) 25 American Journal of Political Science 308; Thomas G Walker and Deborah J Barrow, 'The Diversification of the Federal Bench: Policy and Process Ramifications' (1985) 47 Journal of Politics 596; Sarah Westergren, 'Note: Gender Effects in the Courts of Appeals Revisited: The Data Since 1994' (2004) 92 Georgetown Law Journal 689; Susan W Johnson and Donald R Songer, 'Judge Gender and the Voting Behaviour of Justices on Two North American Supreme Courts' (2009) 30 Justice System Journal 265.

2 E.g. Donald R Songer and Kelley A Crews-Meyer, 'Does Judge Gender Matter? Decision-making in State Supreme Courts' (2000) 82 Social Science Quarterly 750; Jennifer L Peresie, 'Female Judges Matter: Gender and Collegial Decisionmaking in the Federal Appellate Courts' (2004-2005) 114 Yale Law Journal 1759; Pat C Chew, 'Judges' Gender and Employment Discrimination Cases: Emerging Evidence-Based Empirical Conclusions' (2010-2011) 14 Journal of Gender, Race and Justice 359; Susan W Johnson, Donald R Songer and NA Jilani, 'Judge Gender, Critical Mass, and Decision-making in the Appellate Courts of Canada' (2011) 32 Journal of Women, Politics and Policy 233; David Terpstra, 'The Influence of the Gender and Race of the Judge and the Type of Discrimination Charge on Court Case Outcomes' (2013) 55 International Journal of Law and Management 318.

${ }^{3}$ Darrell Steffensmeier and Chris Hebert, 'Women and Men Policymakers: Does the Judge's Gender Affecct the Sentencing of Criminal Defendants?' (1998-1999) 77 Social Forces 1163; Johnson et al., ibid.

${ }^{4}$ Songer and Crews-Meyer, above $\mathrm{n} 2$.

${ }^{5}$ BD Johnson, 'Judges on Trial: A Re-examination of Judicial Race and Gender Effects Across Modes of Conviction' (2014) 25 Criminal Justice Policy Review 159.

${ }^{6}$ Rosemary Hunter, 'Justice Marcia Neave: Case Study of a Feminist Judge' in Ulrike Schulz and Gisela Shaw (eds), Gender and Judging (Hart Publishing 2013).
} 


\footnotetext{
${ }^{7}$ See Rosemary Hunter, Clare McGlynn and Erika Rackley, 'Feminist Judgments: An Introduction' in Rosemary Hunter, Clare McGlynn and Erika Rackley (eds), Feminist Judgments: From Theory to Practice (Hart Publishing, 2010).

${ }^{8}$ Kylie Burns, 'The Australian High Court and Social Facts: A Content Analysis Study' (2012) 40 Federal Law Review 317; Kylie Burns, 'It's Not Just Policy: The Role of Social Facts in Judicial Reasoning in Negligence Cases' (2013) 21 Torts Law Journal 73.

${ }^{9}$ Burns (2012) ibid 317

${ }^{10} \mathrm{Ibid}$.

${ }^{11}$ Ibid.

12 Ibid.

${ }^{13}$ See Diana Majury, 'Introducing the Women's Court of Canada', available at: http://womenscourt.ca/wpcontent/uploads/2009/12/Majury-Intro.pdf.

${ }^{14}$ Special Issue: Rewriting Equality (2006) 18(1) Canadian Journal of Women and the Law, available at http://muse.jhu.edu/journals/canadian_journal_of_women_and_the_law/toc/jwl18.1.html.

${ }^{15}$ Hunter et al., above $\mathrm{n}$ 7. See also http://www.feministjudgments.org.uk.

${ }^{16}$ See Heather Douglas, Francesca Bartlett, Trish Luker and Rosemary Hunter (eds), Australian Feminist Judgments: Righting and Rewriting Law (Hart Publishing, 2014) and http://www.law.uq.edu.au/the-australianfeminist-judgments-project.

${ }^{17}$ See http://www.feministjudging.ie/.

${ }^{18}$ See http://lawprofessors.typepad.com/clinic_prof/2014/08/the-us-feminist-judgments-project-call-forapplications-.html.

${ }^{19} \mathrm{See}$ http://ilg2.org/2014/01/16/invitation-to-participate-in-the-feminist-international-judgments-project/.

${ }^{20}$ Eva Brems (ed), Diversity and European Human Rights: Rewriting Judgments of the ECHR (Cambridge University Press, 2012).

${ }^{21}$ Madhumanti Mukherjee, 'Judging in the Presence of Women as Legal Persons: Feminist Alternative to the Indian Supreme Court Judgment in Sakshi v Union of India' (2012) 1(2) feminists@law.

${ }^{22}$ Case C-158/96 Kohll [1998] ECR I-1931.

${ }^{23}$ Tamara Hervey, 'Re-judging Social Rights in the European Union' in Grainne de Burca, Claire Kilpatrick and Joanne Scott (eds), Critical Legal Perspectives on Global Governance (Hart Publishing, 2013).
} 